\title{
IF I DREAM NOT: UNITY IN “THE COMEDY OF ERRORS"
}

\author{
William Babula \\ University of Miami
}

The unity of The Comedy of Errors lies in the baffling contexts surrounding Aegeon, the boys from Syracuse, and the boys from Ephesus and in their responses to those contexts. Obviously, there are certain differences among these contexts that cannot be ignored. There are differences in the time spans that matter to the play: over twenty-five years for Aegeon, one week in particular for Antipholus and Dromio of Ephesus, and one day for the Syracusans. The degree of seriousness with which Shakespeare handles Aegeon and each of the pairs varies greatly as well. There are differences in temperament. Yet, despite these differences, there is an ultimate similarity of situation and response which binds all five characters into the larger unity of this early comedy.

A single element that ties all of these characters is their fear of destructive change. Least serious in their predicament are the Ephesians. While the errors dismay Antipholus and Dromio of Ephesus, each comes up with a reasonable explanation. This servant is used to beatings. He comments: "I have served him from the hour of my nativity to this instant, and have nothing at his hands for my service but blows" (IV, iv, 31-33). ${ }^{1}$ Similarly, Antipholus of Ephesus blames his wife for what is happening:

Dissembling harlot, thou art false in all

And art confederate with a damned pack

To make a loathsome abject scorn of me . . . (IV, iv, 104106)

These are truly the comic characters. Both, accustomed to life in the city, can find the sources of their discomfiture; they have known them before. Yet while the boys from Ephesus basically provide the farce, they provide it in a pattern that functions to unify the play. In reference to'change, Dromio feels he is being metamorphosed into an "ass" for putting up with such treatment. Antipholus fears he will be turned into an object of "scorn." When the errors leave this Antipholus locked out of his house, he blames it on his wife. She has been troublesome before. His response to the situation is to batter the door down. But when a companion notes such public action would severely damage his reputation, Antipholus, afraid of such a slander on his name, decides instead to get private revenge with the Courtezan. As a leading citizen of Ephesus, he does not want his position destroyed.

Yet there is a greater danger to Antipholus of Ephesus than loss of reputation. While he faces baffling experiences through the 
errors of the comedy, he faces them as well through the actions of his insanely jealous wife. Adriana creates a perplexing context in which he is told he did what he did not do. In fact, her jealousy has changed this man. When he is taken as mad because of certain errors in the play, she explains that he had been undergoing a change all week-before this day of errors: "This week he hath been heavy, sour, sad,/And much different from the man he was" (V, i, 45-46). Apparently she is the cause. Adriana, however, is also fearful of change. On a serious plane she senses the power of devouring time when she asks: "Hath homely age the alluring beauty took/From my poor cheek? . . ." (II, i, 89-90). More realistically she blames her husband:

What ruins are in me that can be found,

By him not ruin'd? then is he the ground

Of my defeatures. My decayed fair

A sunny look of his would soon repair. ...

(II, i, 96-99)

Husband and wife have changed each other for the worse.

Despite these threats of transformation, Adriana and the Ephesian twins are able to explain the maddest events by recourse to the rational. Their problems are presented as essentially comicLuciana reminds the audience that Adriana's pose is comic folly. By contrast, the Syracusans find little comfort in rationality. When Antipholus of Syracuse, near the start of the play, sends off his money with his servant, but soon meets the other Dromio who denies knowledge of the money, Antipholus grows anxious. But it's not just the money; as the language of Antipholus' first soliloquy suggests, a much more serious threat seems involved. The opening lines foreshadow what his brother says when he is caught in the errors. His first response is realistic and unimaginative: "Upon my life, by some device or other/The villain is o'er-raught of all my money" (I, ii, 95-96). But he immediately begins to see much more' serious implications in this opening error:

They say this town is full of cozenage,

As, nimble jugglers that deceive the eye,

Dark working sorcerers that change the mind,

Soul-killing witches that deform the body,

Disguised cheaters, prating mountebanks,

And many such-like liberties of sin ... (I, ii, 97-102).

Commenting upon this passage, Harold Brooks speaks of an "ancient dread of losing the self or soul. . . ."2 Another critic generalizes that "the whole is given a serious turn, a touch of spirituality and of horror."' 3 Certainly to change the mind, body, and soul is to do more than to steal money. Yet the references to 
cheaters and mountebanks go back to the opening lines of the soliloquy and look forward to Antipholus' last line before his exit: "I greatly fear my money is not safe" (I, ii, 105). Antipholus is worried about threats to his existential being and about his money. One threat could be tragic; the other is conventionally comic.

In Act II, ii, Adriana enters and claims the wrong Antipholus for her husband. He protests to her:

In Ephesus I am but two hours old,

As strange unto your town as to your talk;

Who, every word by all my 'wit being scann'd,

Want wit in all one word to understand. (II, ii, 150-153)

His first response is bewilderment. But as she insists, his confusion intensifies, becomes almost philosophic:

What was I married to her in my dream?

Or sleep I now and think I hear all this?

What error drives our eyes and ears amiss? (II, ii, 184-186)

Dromio of Syracuse defines what is happening in terms that echo his master's and foreshadow the Romances: "This is the fairy land: O land of spites!/We talk with goblins, owls and sprites" (II, ii, 191-192). He also turns to religion, "beads," and the sign of the cross for protection. Like Antipholus he appears to feel there is a threat to the soul involved in these errors. Obviously the changes are destructive.

In total intellectual confusion, Antipholus restates his problem in terms that may almost remind us of modern existential absurdity:

Am I in earth, in heaven, or in hell?

Sleeping or waking? mad or well-advised?

Known unto these, and to myself disguised!

I'll say as they say and persever so

And in this mist at all adventures go. (II, ii, 214-218)

Metaphorically, the language points to Antipholus' sense of dislocation, physically; mentally, and in terms of identity. ${ }^{4}$ Life is like a "mist" through which we grope our way. To live is to be lost. To live is to be mad. Or perhaps most importantly, life is like a dream. His question of whether he is sleeping echoes his earlier wonder if he could have been married in a dream or whether Adriana was but part of a current dream. In his last plays Shakespeare will return to a similar vision of life through characters who speak words not unlike Antipholus': Hermione, Posthumus, and Prospero.

Refusing to accept Adriana as his wife, Antipholus woos her sister. She points out the supposed duty he owes Adriana. A halfserious Antipholus in response pleads for intellectual aid: 
Lay open to my earthy-gross conceit, Smother'd in errors, feeble, shallow, weak,

The folded meaning of your words' deceit. Against my soul's pure truth why labour you

To make it wander in an unknown field? (III, ii, 34-38)

His request is not couched in the terms of magic, but in language that can be associated with postlapsarian man. Christian beliefs, like the metaphorical witchcraft, can present man, having fallen, as a "wanderer in an unknown field." All men, like the fallen Adam, have an understanding that is "feeble, shallow, weak." Suitably, Antipholus' wit is limited, "earthy-gross," bound to the world rather than freed by heaven. Thus these Christian notions go to reinforce part of the image of life the play is projecting: life is a complex beyond our understanding.

But Antipholus, when he learns that Dromio has found a "fat marriage" as well, returns to the motif of witchcraft: "There's none but witches do inhabit here. . " (III, ii, 161). And in IV, iii, he comments: "Sure, these are but imaginary wiles/And Lapland sorcerers inhabit here" (IV, iii, 10-11). The references go back to the threat of malignant transformation. At the same time, Antipholus generalizes his situation in other terms which develop the Christian allusions noted above. He responds to one of the errors, the delivery of unasked for gold, with these suggestive words: "And here we wander in illusions" (IV, iii, 43). He repeats the notion that he is groping through a "mist." The danger of metamorphosis and the illusory nature of the world about him are combining to fashion the response of this Antipholus to his context. Thus both Syracusans, in a strange city, resort to "goblins," "sprites," "sorcerers," and "witches" to express the threat they feel from an incomprehensible environment of change and illusion.

In contrast, ihe denizen twins respond to situations with reasonable complaints rather than with a belief in "a series of adventures with the supernatural." 5 Yet it is almost their rationality that makes them creatures of farce. For example, it is pure error comedy when Antipholus of Ephesus is arrested for the gold chain he never received. For him it is just another ridiculous mistake in a rather bad day. He reacts by sending for bail; but he gives the message to the wrong Dromio:

Tell her I am arrested in the street

And that shall bail me: hie thee, slave, be gone!

On officer, to prison till it come. (IV, i, 106-108)

Dromio of Syracuse goes to Adriana, but note how he converts Antipholus' blunt description into an action that has "soul-killing" 
implications and one that can be presented in language that harkens back to the Christian overtones in the wooing of Luciana:

A devil in an everlasting garment hath him;

One whose hard heart is button'd up with steel;

A fiend, a fury, pitiless and rough ... .

One that before the judgment carries poor souls to hell.

(IV, ii, 33-40)

Like Antipholus' language when he was anxious about his money, this metaphor for an "officer" extends the significance of what is happening. Apparently, though these lines are comic, the boys from Syracuse feel much more threatened by inexplicable events than their brothers in Ephesus who have the advantage of custom.

Yet, while both pairs are bewildered by events, Shakespeare presents verbally the situation of the Syracusans as more serious. Most serious, however, is the position of Aegeon. Though ignored in the central comedy, he has been identified with his Syracusan son from the outset of the play. When Aegeon is led off condemned, the alien Antipholus is warned that the same thing could happen to him:

Therefore give out you are of Epidamnum,

Lest that your goods too soon be confiscate.

This very day a Syracusan merchant

Is apprehended for arrival here. . . (I, ii, 1-4)

Then the errors begin. Antipholus of Syracuse tries in the comedy to cope with difficult, perplexing, and madly shifting life situations. But on another level the same might be said of Aegeon. If comic confusion has overwhelmed Antipholus of Syracuse, the serious confusion of life has perplexed, and is about to destroy his father. With the opening tragic note sounded, Aegeon in the rest of the first scene tells a sad tale that functions as a serious mirror of the farcical actions. ${ }^{\beta}$ He begins as "prosperous" until his "factor's death" forces him to undertake a journey. His wife follows and gives birth to twins, urges her husband to return, and he "unwilling" agrees. The journey on the treacherous sea begins. Soon a storm rises. They abandon the "sinking-ripe" ship, tie each twin (and each Dromio) and themselves to either end of a mast. The sky clears and ships are spotted; apparently Fortune has made another turn.

Relief is only momentary, however, in this Greek Romance. Their mast breaks as two ships approach and the family (and the Dromios) are split apart and picked up by two different ships. All of this action is summarized by the condemned Aegeon:

Thus have you heard me sever'd from my bliss,

That by misfortunes was my life prolong'd

To tell sad stories of my own mishaps. (I, i, 11.9-121) 
His life, his "mishaps" parallel the day spent by his son in Ephesus. It is as if Antipholus' experiences were taken seriously and expanded in time. For five years Aegeon has sought his lost son: Five summers have I spent in furthest Greece,

Roaming clean through the bounds of Asia, And, coasting homeward, came to Ephesus;

Hopeless to find. ... (I, i, 133-136)

On his geographical scale he has found no more about what he wants to know than Antipholus of Syracuse has found out about the whirling system of events about him. In a different sense his son's condition appears "hopeless." When Aegeon closes the first scene with this comment: "Hopeless and helpless doth Aegeon wend ..." (I, i, 158), the sound is tragic. Yet Antipholus is certainly "hopeless and helpless" in his farcical context. Shakespeare is using tragedy and comedy to shape parallel experiences especially for Aegeon and his son from Syracuse. Of course, although to a lesser degree, the other baffled characters discussed share in similar experiences.

However, it is through their concern with transformation that Aegeon and the two pairs are united. Antipholus of Ephesus was being changed by the jealousy of his wife; his servant was being beaten into an ass. As Brooks points out, "The alien Antipholus and Dromio fear Circean metamorphosis; Aegeon, that he has been deformed out of recognition by time." 7 In the last scene Aegeon is brought out for execution but sees Antipholus and Dromio of Ephesus. He makes the fairly logical error of assuming these are the men from Syracuse. But when they deny knowing him, he laments:

$O$, Grief hath changed me since you saw me last.

And careful hours with time's deformed hand

Have written strange defeatures in my face:

But tell me yet, dost thou not know my voice? (V, i, 297-300) Aegeon speaks in the same terms that Antipholus of Syracuse applied earlier to his experience of the city of Ephesus: in it sorcerers could "change the mind" and witches "deform the body."

In the tragic frame the vague but dangerous witches and sorcerers-they are described as "soul-killing"-that Antipholus blamed for his experience of errors are made to coincide with specific elements of human existence. Instead of a sorcerer, grief has changed Aegeon. Instead of a witch, time has deformed him. The importance of time as a deformer is emphasized when Aegeon continues his complaint about not being recognized:

O time's extremity,

Hast thou so crack'd and splitted my poor tongue 
In seven short years, that here my only son

Knows not my feeble key of untuned cares?

Though now this grained face of mine be hid

In sap-consuming winter's drizzled snow

And all the conduits of my blood froze up,

Yet hath my night of life some memory,

My wasting lamps some fading glimmer left,

My dull deaf ears a little use to hear:

All these old witnesses-I cannot err-

Tell me thou art my son Antipholus. (V, i, 307-318)

$\mathrm{He}$ is right; but it is not the son Antipholus he thinks it is. Thus experience has baffled him as it has baffled Antipholus of Syracuse. While Antipholus fears the serious inslications in systems that cannot be arranged by the mind, Aegeon's very life, his suffering, has been just such a system.

In a few moments, however, Shakespeare resolves the dilemma through various recognitions. Brooks notes that the restoration of the family relationship with all its implications is the central concern of the play. ${ }^{8}$ Yet the comedy has also been concerned with shaping seemingly illusory contexts that bewildered characters and threatened them with deforming changes. It is in the delineation of these experiences that much of the structural unity of the play lies. There is a kind of dramatic unity, as well, in the responses of certain characters to these experiences. While all the major characters may, to different degrees, agree with the response I am leading to, it is given expression by the two characters who are perhaps the most baffled: Aegeon and Antipholus of Syracuse.

The alien Antipholus has faced the whirling confusion of the comedy, presented in metaphors of witchcraft and even of fallen man; Aegeon has faced the near tragic accidents of life, and suffered under the deforming power of time. The story of Aegeon might be the story of Antipholus on another perceptual plane. The image of life, its confusion, its uncertainty, its grief (whether tragic or comic), remains the same. Thus for both Antipholus and Aegeon life comes to have a dreamlike quality. While there is a comic resolution with the appearance of both sets of twins on the stage and the revelation of Aemilia, Aegeon and Antipholus still hold this perplexity-formed vision of life. Both characters have learned to be cautious; they both fear this new turn of events may be as unreal as certain past experiences, another dream. Like Alonso when he finds Ferdinand, they fear the fortunate twist may be but another bit of cozenage. Aegeon is careful with his newly discovered wife as he was not when he thought he recognized his son: "If I dream not, thou art Aemilia" (V, i, 352). Similarly, Antipholus 
promises to marry Luciana, "If this be not a dream I see and hear" (V, i, 376).

Admittedly, at this point the prosaic Antipholus denizen has little to say. In fact, everything apparently worked out as he would expect; there is a reasonable explanation. Perhaps he would not consider life as a dream. Yet he has been threatened as were his brother and father. If he is content, it is because he lacks the imagination of his brother. He has not learned much. Aegeon, however, through the tragic experiences of his life, through the susceptibility of that life to time, has felt the unstable and misty nature of existence. The comic perplexities of a frightful day in Ephesus have made the same metaphysical impression upon his son from Syracuse. For each, life has come to be like a bewildering dream. Each has become aware that his apprehension of life is "smother'd in errors, feeble, shallow, weak." Thus Shakespeare has unified his play through a combination of change-threatening experiences at every level and the highly imaginative responses to those simultaneously real and illusory threats made by Aegeon and alien Antipholus on the highest perceptive plane. For both have felt, as the comedy made them feel, that to move through life is to grope through a misty dream.

\section{NOTES}

1. The Complete Works of Shakespeare, ed. Hardin Craig (Glenview, Ill.: Scott, Foresman, 1961). All citations in my text are to this edition.

2. Harold Brooks, "Themes and Structure in The Comedy of Errors," from Early Shakespeare, ed. J. R. Brown and B. Harris (London: Edward Arnold, 1961), rpt. in Kenneth Muir, ed., Shakespeare: The Comedies, Twentieth Century Views (Englewood Cliffs, N. J.: Prentice-Hall, 1965), p. 15. The best article on the play.

3. Louise George Clubb, "Italian Comedy and The Comedy of Errors," CL, 19,3 (1967), 241.

4. Brooks develops the importance of identity in the play. See especially pp. 21-23.

5. Brooks, p. 20.

6. See Bertrand Evans, Shakespeare's Comedies (1960; rpt. New York and London: Oxford University Press, 1967), for the importance of the tragic note struck in the opening scene.

7. Brooks, p. 21. In his otherwise excellent article Brooks ignores the threat of transformation to the Ephesian twins which ties their situation to that of Aegeon and the Syracusans.

8. Brooks, pp. 20-21 stresses reunification over the lingering perplexity. 